\title{
XXXIX.-On the Genera and Species of Lacunidæ found in
}

Japan.' By Arthur Adams, F.L.S. \&c.

The Lacuna have been separated by Dr. Gray from the Littorina, with which they are usually associated, on account of the peculiar appendiculate opercular lobe, which is expanded at the sides and furnished with two beards behind. The animal, moreover, has no jaws, whereas in the Littorinidæ they are distinct and horny. The Japanese seas furnish us with examples of all the known generic and subgeneric forms, and likewise with a new and peculiar type which I am inclined to refer to this family.

\section{Fam. Lacunidæ.}

\section{Genus Lacuna, Turt.}

\section{Lacuna latifasciata, A. Adams.}

$\boldsymbol{L}$. testa depresso-semiglobosa, tenui, late et profunde umbilicata ; spira parva, laterali; alba, fascia lata rufo-fusca ornata; anfractibus 3 , planiusculis, rapide crescentibus; apertura semiorbiculari, regione umbilici rufo tincta; columella recta, angusta.

Hab. Kino-O-Sima.

A species of the same form as L. pallidula, Da Costa, but of much smaller size, and ornamented with a broad red-brown band.

Subgenus Medoria, Leach.

Medoria turrita, A. Adams.

Lacuna turrita, A. Adams, Ann. \& Mag. Nat. Hist. 1861. $H a b$. Rifunsiri.

Subgenus Epheria, Leach.

1. Epheria decorata, A. Adams.

Lacuna (Epheria) decorata, A. Adams, Ann. \& Mag. Nat. Hist. 1861. Hab. Rifunsiri.

2. Epheria inflata, A. Adams.

Lacuna inflata, A. Adams, Ann. \& Mag. Nat. Hist. 1861. $H a b$. Rifunsiri.

3. Epheria carinifera, A. Adams.

Lacuna carinifera, A. Adams, Proc. Zool. Soc. 1851, p. 225. Hab. Takano-Sima.

\section{Epheria lepidula, A. Adams:}

$\boldsymbol{E}$. testa depresso-conica, perobliqua, late umbilicata ; spira brevi, acuta; alba, opaca ; anfractibus 3 , convexiusculis, ultimo ad peri- 
pheriam angulato; apertura semiovata; labio recto, acuto; um* bilici margine carinula acuta circumcincto.

Hab. Seto-Uchi; Akasi; 15 fathoms.

A small white species from the Inland Sea of Japan, with the margin of the wide umbilicus encircled by a narrow elevated keel.

\section{Genus Stenotis, A. Adams.}

Testa compressa, elongato-ovata, auriformis ; spira brevi, acuta ; anfractibus planis, simplicibus, ultimo sejuncto. Apertura oblonga, postice angustata; peritremate acuto, recto, continuo, integro.

I have founded this genus on a little shell which I obtained in the Inland Sea of Japan, and also at Yobuko, a small harbour on the west coast of Kiusu. It possesses some of the characters of Fossar, and reminds one of Vanikoro: in form it resembles somewhat a minute Naticina; but perhaps its true relations are with Lacuna, although the members of that family are littoral in their habits.

\section{Stenotis laxata, A. Adams.}

S. testa elongato-ovali, compressa, tenui, sordide alba; spira parva, acuta ; anfractibus 3 , planiusculis, rapide crescentibus; anfractu ultimo magno, soluto, antice dilatato; apertura auriformi, postice angustata ; umbilico patulo, margine angulato.

Hab. Idsuma-Nada; 17 fathoms. Yobuko, west coast of Kiusu; 14 fathoms, mud.

XL.-On the Structure of the Valves of Pleurosigma and other Diatoms. By G. C. WALLICH, M.D., F.L.S., F.G.S., \&c.

In a scientific point of view, it is obviously immaterial whether the markings on a Diatom-valve present this or that configuration, or whether minute points on its surface consist of elevations or of depresșions. At all events, the physiology of the Protophytes, so far as we have heretofore become acquainted with it, does not appear to have been advanced a single step by the fitful controversy that has taken place on the subject, with no better result than that of rendering it distasteful to the generality of scientific readers.

But, notwithstanding this, it cannot be denied that the accurate determination of the nature of these markings is of great importance indirectly, that is to say, by furnishing a standard wherewith to gauge the powers of our highest optical combinations, and enable us to pronounce with some approach to confidence when minute appearances are, or are not, illusory. In this sense the subject may be regarded as bearing essentially 


\section{$2 \mathrm{BHL}$ Biodiversity Heritage Library}

Adams, Arthur. 1863. "XXXIX.—On the genera and species of Lacunidæ found in Japan." The Annals and magazine of natural history; zoology, botany, and geology 11, 350-351.

View This Item Online: https://www.biodiversitylibrary.org/item/72232

Permalink: https://www.biodiversitylibrary.org/partpdf/61198

\section{Holding Institution}

University of Toronto - Gerstein Science Information Centre

\section{Sponsored by}

University of Toronto

\section{Copyright \& Reuse}

Copyright Status: NOT_IN_COPYRIGHT

This document was created from content at the Biodiversity Heritage Library, the world's largest open access digital library for biodiversity literature and archives. Visit BHL at https://www.biodiversitylibrary.org. 